\title{
Can continuous disclosure improve the performance of State-Owned Enterprises?
}

May 2011

Talosaga Talosaga, Dave Heatley \& Bronwyn Howell

New Zealand Institute for the Study of Competition and Regulation Inc.

PO Box 600, Wellington, New Zealand.

Email: talosaga.talosaga@vuw.ac.nz

The views in this paper solely reflect those of the authors, and do not necessarily represent those of the institutions with which they are affiliated or their constituent members. Any errors or omissions remain the responsibility of the authors. 


\section{Executive Summary}

In January 2010 the New Zealand Government introduced a continuous disclosure regime for State-Owned Enterprise (SOEs) modelled on the regime applying to publicly-listed companies (PLCs). The government sees continuous disclosure increasing the transparency of SOEs, and that this will lead to improved financial performance by SOEs. We analyse the traditional rationales for continuous disclosure in PLCs, and find that it is not axiomatic that a continuous disclosure regime designed for PLCs overlaid onto an SOE will offer the same incentives for performance improvement. The differences in owner identity and governance relationships in SOEs and the absence of a market for the trading of shares substantially weaken the performance improvement effect of the disclosure instrument in SOEs. In the absence of share trading, it is not clear how a failure to disclose by SOE managers could be detected. Furthermore, under the New Zealand arrangements, the sanctions for SOE failure to disclose are very weak. This suggests that it is both easier for and more likely that SOE managers will withhold material information relative to their PLC counterparts. The hypothesis appears confirmed by a matched-pair comparison of disclosures by SOEs and private sector firms in the first year of the SOE continuous disclosure regime. 


\section{Can continuous disclosure improve the performance of State-Owned Enterprises?}

\section{Introduction}

"The State-Owned Enterprise model established under the 1986 SOE Act, arguably represents the best attempt to have efficient public businesses. The SOE model has a number of characteristics that suggest SOE business performance will not exceed that of privately-owned firms." (Boles de Boer \& Evans, 2000, pp.4-5).

"We have been through a period of high investment [in SOEs] but have not seen a flow on into profits or dividends. The Crown, as owner of these assets, is not yet seeing a return commensurate with the value of its investments." (COMU, 2010, p.5)

"The Government is increasing its focus on the [SOE] commercial portfolio to ensure that it is being managed as effectively as possible. Crown-owned commercial activities do not face the same market scrutiny as listed companies, but we believe it is important to replicate market disciplines as much as possible. We are increasing transparency in several ways including continuous disclosure requirements for SOEs, annual public meetings and publication of performance information." (COMU, 2010, p.2)

As part of the reforms of New Zealand's state sector beginning in the 1980s, many government trading activities were separated out into stand-alone companies, known as StateOwned Enterprises (SOEs) ${ }^{1}$. The rationale was for these new entities to replicate as far as was possible the institutional structures and governance arrangements of privately-owned firms. Furthermore, the firms would be exposed to competitive market disciplines. These measures were proposed as means of addressing the lacklustre financial performance of the trading activities under monopolised government department structures. Key features of the SOE model which directly paralleled private sector structures were the imposition of limited liability status (i.e. it was not axiomatic that SOEs would be protected by Crown immunity), and the separation of ownership and control. Ownership of a shareholding interest was vested in an arms-length Minister and control was vested in a Board of Directors to undertake primary governance responsibility for the operation of the entities.. Financial performance

\footnotetext{
${ }^{1}$ A state-owned enterprise is an entity owned by a government that is engaged in commercial activities and is expected to be run as a profitable business. Outside of New Zealand similar entities are known as government-owned corporations or government business enterprises.
} 
improvement was presumed to arise from greater transparency, role clarity and the alignment of incentives to commercial rather than political objectives (Horn, 1995).

Whilst some improvements in financial performance have accrued from the creation of the SOEs (Boles de Boer \& Evans, 2000), the opening quotations illustrate that the gains have been less than anticipated. SOEs do not appear to be performing as efficiently as their private sector counterparts. This is of considerable concern given the extent to which SOEs dominate New Zealand's infrastructure investment - a segment which in most comparator economies is predominantly privately held (Capital Market Development Taskforce, 2009). As successive governments have pledged to retain majority, if not complete ownership of these SOEs in the medium term, policy-makers have been charged with finding new mechanisms via which SOE financial performance might be improved. Given that the creation of SOEs was inspired by the overlaying of structural and governance features from privately-held firms onto SOEs, it is unsurprising to find that remaining differences between the SOE and Publicly-Listed Companies (PLCs) were examined to determine whether other instruments transferred across might lead to SOE performance improvements.

On 21 January 2010, New Zealand's National Government announced the introduction of a 'continuous disclosure regime' for the nine largest $\mathrm{SOEs}^{23}$. The regime requires each SOE to disclose to the public the fundamental terms of any material transactions entered into, and any information that has a material impact on the SOE's commercial value, as soon as the SOE becomes aware of this information ${ }^{4}$. This disclosure regime mirrors similar regimes for PLCs on the New Zealand Exchange (NZX) and stock exchanges around the world. The Government's stated intent is to open SOEs up to greater monitoring by citizens and analysts, which is hoped to induce better performance by SOE managers.

The overlaying of a PLC-inspired continuous disclosure regime onto SOEs leads to the question of whether the obligation will necessarily lead to the desired performance improvements. Answering the question necessitates a detailed examination of the purpose and effect of the instrument in the PLC context, and the extent to which the SOE context mirrors or deviates from the PLC one. The key factor for consideration would appear to be the identity and incentives facing the respective differing ownership interests. Continuous disclosure by PLCs provides information to shareholder-owners enabling them to better exert

\footnotetext{
${ }^{2}$ http://www.beehive.govt.nz/release/more-disclosure-soes Accessed 1 December 2010.

${ }^{3}$ NZ Rail Corporation, Transpower, Meridian, Mighty River Power, Landcorp, Genesis, NZ Post, Solid Energy and Kordia.

${ }^{4}$ http://www.comu.govt.nz/resources/pdfs/disclosures/soe-discl-rules-dec09.pdf Accessed 1 December 2010.
} 
their ownership interests via the firm's governance arrangements. But are the same opportunities and incentives likely to apply when the ownership interests and the execution of formal governance instruments are concentrated in the hands of a shareholding minister rather than in the beneficial-owner citizens? From an assessment of the transferability of the continuous disclosure instrument, this paper concludes that significant differences in the SOE context mean that the imposition of continuous disclosure obligations on SOEs is unlikely to substantially reduce the financial performance gap between SOEs and private enterprises.

The paper proceeds as follows. Section 2 explains the difference between continuous and periodic disclosure. In Section 3, we evaluate the theory of self-induced disclosure and explain why voluntary disclosure may be suboptimal. Section 4 outlines the three main rationales for a continuous disclosure regime in the private sector, and how these benefits change when the regime is applied to SOEs. We then discuss whether increased transparency can improve SOE performance in Section 5. Section 6 discusses the credibility of the regime and evaluates how well it has performed over the first 15 months of operation. Section 7 concludes.

\section{Continuous vs. periodic disclosure}

Continuous disclosure regimes require companies to immediately disclose material information to the public via a formal channel accessible equally to all interested stakeholders when executives first become aware of its existence (usually via a formal channel accessible equally to all interested stakeholders, such as the web site of the stock exchange on which the firm is listed). For PLCs, material information is defined as information that, if it were available, would have a material impact on the price of a company's shares. This may include information like a natural disaster disrupting the operations of a business, changes in key strategic or operational imperatives or the agreement of a contract with an essential supplier. Periodic disclosure, on the other hand, requires that a company release a specific set of information about the company at regular intervals, for example annual and quarterly reports. This paper focuses on continuous disclosure, assuming that the requirement of periodic disclosure is already in place. That is, we will be considering the utility of continuous disclosure over and above periodic disclosure.

\section{The theory of self-induced disclosure}

A principal-agent relationship is where a person (the principal) engages another person (the agent) to perform an action on their behalf (Jensen \& Meckling, 1976; Eisenhardt, 1989). Generally the principal and agent have differing interests, which means an unconstrained agent cannot be expected to act perfectly in the interests of the principal. The most commonly 
studied example of this relationship is between the owners of a firm and the firm's management ${ }^{5}$; however the agency problem can be found in all areas of cooperative endeavour including the coordination of entities in the same layer of a hierarchical structure, for example between shareholders.

Agency costs are the additional costs of using an agent compared to the principals undertaking the task themselves. Agency costs arise because the agents and principals, in general, have:

- different interests;

- different attitudes to risk; and

- different access to information (information asymmetries).

In a company with separated ownership and control, shareholders would like the managers of a company to take actions that increase shareholder wealth. Managers on the other hand may prefer to act in their own interest, for example by putting less effort into the tasks. Shareholders can be expected to explicitly trade-off between monitoring and the creation of incentives in order to minimise the costs (including mitigating the risks) of imperfect agency (Milgrom \& Roberts, 1992). Importantly, the design of monitoring and enforcement regimes and incentive mechanisms is contingent upon the principal's ability to obtain relevant, credible information in a timely manner.

This paper focuses on the information asymmetries that arise between shareholders and managers. Shareholders benefit from greater disclosure of information because it allows them to better constrain the actions of their agents. However, managers may prefer not to disclose information that reflects badly on their managerial skills or directly affects their compensation.

The theory of self-induced disclosure states that managers have an incentive to disclose all material information without government regulation (Easterbrook \& Fischel, 1984). There are two main sources of this incentive. First, disclosing information will make shares in the company more attractive to investors. Thus the firm will be able to sell its shares for a higher price, or they will be traded at a higher price on the secondary market. If a manager's compensation is tied to the company's share price, the manager has an incentive to disclose the efficient level of information. Second, the manager has an interest in maintaining a

\footnotetext{
${ }^{5}$ For our purposes, we define management to be a company's board of directors and its senior management team. More detailed models might examine the principal-agent relationship between the board and senior management.
} 
reputation as a good manager (good meaning good for investors), as this will lead to greater employment opportunities in the future and a larger future income. This may also include future interactions with the manager's current employer, for example renegotiating compensation. Thus the manager will maximise her future expected income by disclosing all material information.

The primary flaw in this argument arises because investors cannot easily distinguish between a firm that discloses all information and a firm that discloses most information but withholds some $^{6}$. If investors cannot distinguish between the firms, managers have an opportunity to withhold some information from shareholders without facing the penalty from a decreased share price. A manager who has an incentive not to disclose material information, for example to hide mistakes, will thus choose to withhold information in some circumstances. Knowing this, investors will treat all firms on the basis that some information may have been withheld. Consequently, the incentives to disclose are negated. As disclosure is costly to the manager, the quantum of information disclosed even by 'honest' managers will decrease. At the extreme, where consumers have no way at all to distinguish between credible information and cheap talk, the equilibrium outcome is no voluntary information disclosure at all - indeed, shareholders may have to explicitly compensate managers for the cost of its production to induce the disclosure of any information at all (Prendergast, 2003).

Another weakness of voluntary disclosure regimes is that unregulated managers can change how much focus the media and investors put on their disclosure by changing the timing of its release. For example, a manager may release information on the same day as a major event (for example, a sporting match) or on a Friday in the hope that it will receive less attention. Thus a manager can time the release of bad news to ensure fewer investors see the disclosure. With continuous disclosure, managers are forced to disclose information as soon as it comes to hand, meaning they cannot delay disclosure to a more opportune time.

These weaknesses in the theory of self-induced disclosure are supported by empirical evidence. If the theory of self-induced disclosure applied, we would expect the introduction of continuous disclosure rules to have no impact on the frequency of disclosure. Dunstan, Gallery and Truong (2008) present evidence that statutory backing of the NZX's continuous disclosure rules increased the frequency of disclosures significantly. They studied the eightyear period 1998-2005 (inclusive) looking at management earnings forecasts in disclosures. From 1998-2002, the NZX continuous disclosure regime had no legislative backing, which

\footnotetext{
${ }^{6}$ This is an application of Akerlof's (1970) seminal analysis of the 'Market for Lemons'.
} 
limited the severity of punishments that could be issued for nondisclosure. With the passing of the Securities Markets Amendment Act 2002, punishments for nondisclosure could be issued by the Securities Commission up to $\$ 30,000$, and by the courts up to $\$ 300,000$. If the theory of self-induced disclosure were correct, one would expect no change in the frequency of disclosures after the passing of the law, since all managers were already disclosing all information they were required to. Instead, the three found that the frequency of disclosures increased significantly after 2002 , consistent with our critique of the theory.

Under the theory of self-induced disclosure, we would also expect managers to release material negative information as soon as it comes to hand. ${ }^{7}$ Pastena and Ronen (1979) provide evidence that managers try to delay the disclosure of negative information, relative to positive information, and that managers generally only disclose negative information when a third party is likely to disclose the information anyway. Once again, this evidence does not support the theory of self-induced disclosure.

Considering the theoretical and empirical evidence presented above, we conclude that the theory of self-induced disclosure is unsupported. Managers will withhold some material information when it is personally advantageous for them to do so, at the expense of shareholder-principals. In principle, therefore, a continuous disclosure obligation is desirable so long as the benefits arising exceed the costs of compliance.

\section{Rationales for continuous disclosure in PLCs}

In this section we outline the three major rationales for a continuous disclosure regime when applied to publicly listed companies: informing investors, preventing insider trading and reducing information acquisition costs. Each is examined in turn, with a discussion of its applicability to the SOE context.

\subsection{Informing investors}

One of the risks an investor faces when trading in a company's shares is that he does not have the most up-to-date information. Periodic disclosure cannot remove this risk. A company that reported honestly that it was performing well in its last annual report may get into financial difficulty during the subsequent year. The manager may not disclose this information, fearing it would reflect badly on her performance, and hoping that she would be able to rescue the situation before the next periodic disclosure. If an investor is not aware of this information, he

\footnotetext{
${ }^{7}$ When trading, an investor would prefer to have the most up to date information available. Thus, delaying the disclosure of information harms investors just like not disclosing information. This is discussed further in Section 4.1 below.
} 
may unwittingly invest in a company at a share price much greater than its underlying value. Continuous disclosure removes the risk of trading on out-of-date information because if the underlying value of the company changes, the manager is required to disclose this information immediately.

In the case of SOEs, the ultimate investors are taxpayers and citizens since they bear the financial consequences arising from residual profit or residual loss from the activities of SOEs. However, citizens cannot trade their ownership shares in SOEs. They can only affect their level of investment in SOEs by voting in a government with a policy to divest or reinvest in SOEs. As citizens only have this opportunity once every election cycle, there is no timeliness imperative for information to be released 'continuously'. Instead a detailed periodic disclosure would suffice.

Furthermore, under the SOE arrangements, the primary beneficiary of any information disclosed for the purposes of informing investors is the shareholding Minister, and his monitoring agents the Crown Ownership Monitoring Unit (COMU). A continuous public disclosure regime adds nothing to COMU's ability to engage in its SOE's performance monitoring as the unit has access to a very much larger body of information than the standard public announcements by the SOEs ${ }^{8}$.

It could be argued that the SOE continuous disclosure regime might perform a role by providing information that can be utilised by the media or politicians to highlight elements of SOE performance. However given limited extent to which voters can influence SOE managers, and the objectives of the structural changes in the 1980s designed to minimise the extent to which political imperatives could dilute SOEs' pursuit of financial performance objectives, it is debatable how the instrument used in this manner could lead directly to improved SOE performance. Rather, it is more likely to be utilised indirectly as a means of affecting the voting public's perception of the performance of the shareholding Minister's discharge of his duties rather than the commercial performance of the firm and the incentives facing its managers. This is discussed further in Section 5.

\subsection{Preventing insider trading}

Insider trading is when a person (an insider) - who has material information about a publicly listed company that is not available to the public - trades in a company's shares on the basis of this non-public information. Inside information allows an insider to make a more accurate

\footnotetext{
${ }^{8}$ http://www.comu.govt.nz/about-comu/our-role/
} 
valuation of the company's share value. Because this information is non-public, it is not reflected in the company's share price. Thus the insider will be able to make an easy profit from this information by buying shares when they are undervalued and selling when they are overvalued. This is supported empirically by Etebari, Tourani-Rad and Gilbert (2004).

Insiders appropriate some of the return from investment from other shareholders, lowering the value of those shares to outside shareholders (Manove, 1989). Imagine an investor is considering buying shares in two companies, A and B. Company A has somehow made insider trading in its shares impossible, but insider trading in company B is still possible. In all other respects, the two companies are identical. Investors know that if they invest in company B, they may at some point unwittingly trade with an insider. Because the insider has a more accurate valuation of the company's shares, she will be able to buy when the stock is undervalued or sell when it is overvalued and make a profit. The counterparty in the trade, the outsider, will be worse off because the trade is zero sum. A potential investor, knowing that in the future he may unwittingly trade with an insider and be made worse off, will lower his valuation of the company's shares. Thus, investors will value company A shares higher than company B shares. This too is supported empirically. Bhattacharya and Daouk (2002) draw on data from 103 countries around the world to show that enforcement of insider trading laws lowers the cost of equity for firms (i.e. increases their share price). Ojah, Muhanji and Myburg (2008) provide empirical evidence from South Africa showing that effective prohibition of insider trading led to a decrease in the cost of equity.

Thus insider trading leaves the company worse off because its market value is lower and it is harder to acquire capital to fund investment. Investors are made worse off because part of their return on investment is appropriated by insiders, and society is worse off because there is lower investment (Ausubel, 1990) and equity is not allocated to the most productive investments.

An insider, upon receiving insider information, will want to delay its release to investors so that they have time to trade on the share market before this information is incorporated into the share price. Continuous disclosure requires insiders to immediately disclose material information to the public, leaving them with no opportunity to trade on the share market. Thus a properly functioning continuous disclosure regime will help prevent insider trading. (Dennis, 1987) 
As SOEs have no tradeable shares, and therefore no possibility exists of insider trading occurring, there is no societal benefit available from this aspect of continuous disclosure by SOEs.

\subsection{Reducing information acquisition costs}

The third rationale for continuous disclosure is the reduction of information acquisition costs. Information costs are costs associated with searching for and verifying information about, in this case, a firm. As discussed above, those managing firms have an incentive to withhold material information from investors for a variety of reasons. However, this information is still valuable to investors, so they will be willing to incur some information costs to find this information and use it to make better informed investment decisions.

Furthermore, once an investor, or analyst employed by that investor, obtains material information, it is often in their interest to prevent the further dissemination of this information to other investors. An investor who has access to material information about a company, which is unavailable to other traders, is at an advantage and is able to earn a profit by trading on the basis of their information. By passing this information on to other investors, the initial investor destroys the advantage the information gave him, and so the investor has an incentive to withhold this information, in much the same way an insider does. This leads to further costs. First of all, the initial investor could theoretically pass on the material information to other investors at a very low cost. This would lead to the other investors being better off from being able to make better informed investment decisions, and would lead to prices of securities being a better reflection of the underlying value of those securities, leading to a more efficient allocation of capital. Second, other investors who don't have access to this information may choose to incur information costs themselves to obtain this information. Thus investors as a group may incur the same information cost multiple times to obtain the same information, when it was possible for only one investor to incur these costs and distribute the information to the other investors at relatively low cost.

Continuous disclosure can reduce the information costs incurred by investors by requiring the manager to directly disclose all material information. The manager gains access to material information in her everyday duties in the company. In other words, she gains access to material information at close to no cost. ${ }^{9}$ This information is then submitted to the stock

\footnotetext{
${ }^{9}$ There may be costs associated with the internal information systems of a company, for example reports from departments about their operations. However, these costs would have been incurred even without continuous disclosure, as they are necessary for the company to function properly. Thus these internal information system costs cannot be considered as costs of continuous disclosure.
} 
exchange which can then easily disseminate this information to investors through. Another way of looking at the issue is that the manager in choosing to withhold material information imposes an external cost on investors. One may expect this social cost to be dealt with or internalised by interactions between the manager and investor (Coase, 1960). This is effectively what the proponents of the theory of self-induced disclosure claim. As explained above, this does not occur because the interests of the manager and the investors cannot be perfectly aligned.

Let us now turn our attention to SOEs. Investors in SOEs and publicly listed companies are very different. Investors (and potential investors) in a PLC can quickly and easily buy and sell shares in that company. In contrast, the only way in which citizens can affect their level of investment in SOEs is vote for a government with a policy of acquiring, divesting or reinvesting in SOEs. That means the value of material information about SOEs is very low for individual citizens. Therefore, we expect very few people are incurring information costs to search for information about SOEs. Indeed, most of the analytical activity surrounding New Zealand SOEs is undertaken by COMU, using both publicly-available information and that acquired under separate statutory powers and negotiated agreements. Furthermore, the information collected by COMU is likely very different in its nature given that in the absence of share trading, very different processes must be used to assess the SOE's financial performance (Jensen, 1993). Thus, the costs of COMU's information acquisition are unlikely to be very different either with or without a continuous disclosure regime in place. Indeed, the obligation likely increases COMU's direct costs, as it must provide the means via which the disclosed information is made publicly available (i.e. the website) and the monitoring and enforcement activities required to ensure SOEs comply with the new obligations.

Consequently, if the total information costs incurred by parties other than COMU in monitoring SOEs are very small, then reduction in information costs from having a continuous disclosure regime must also be very small. Indeed, the effect might actually be a net decrease in efficiency if the obligation to disclose leads to increases costs for the SOEs, but external parties fail to utilise the information as a consequence of there being no material benefit available to them from doing so.

\section{Transparency and improved performance}

The rationale put forward by the New Zealand government for its SOE continuous disclosure regime is that it will support and increase the transparency of SOEs. The proposition is that increased transparency will make managers more accountable for SOE performance, and give them a greater incentive to improve that performance. This Section develops a simple 
principal-agent model of a PLC, and then contrasts it with a model of an SOE to assess the likelihood of the policy objectives for increased transparency being realised. Finally, the implications of this model on the ability of citizens to monitor managers will be discussed, along with why incentives for monitoring are necessary for effective operation of a continuous disclosure regime are necessary, but not present in the New Zealand SOE model.

\section{Figure 1: PLC agency relationship}

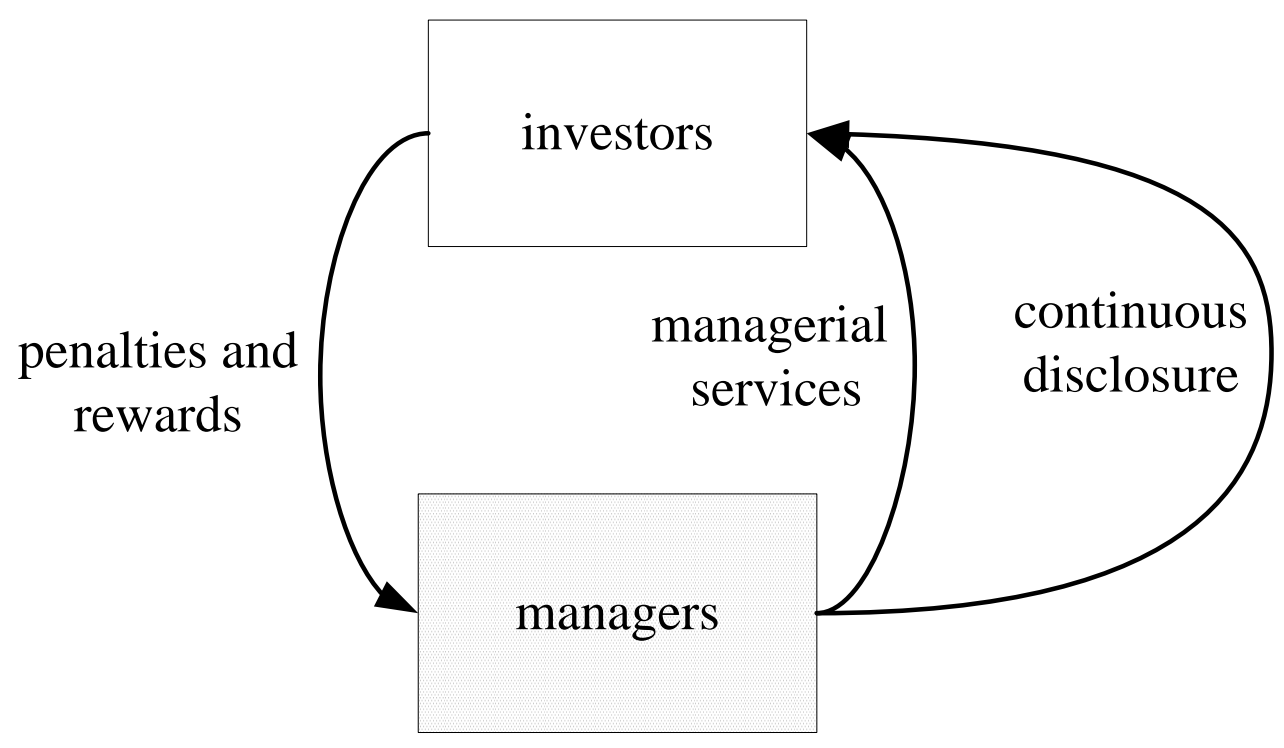

The relationship between investors and managers is a classic example of a principal agent relationship (Figure 1). In a publicly listed company, investors (the principals) hire management (the agents) to run the company on their behalf. Investors want the company to be run to maximise shareholder returns, whereas management may prefer to maximize their own returns, for example by spending less effort running the business or choosing low risk projects to increase their job security. Investors have incomplete information about the performance of the management. To counteract this, the principal will put in place measures to induce the agent to act in the principal's interests. Examples of such measures are performance-based pay and close monitoring of the agent's actions. However, because principals generally have incomplete information about the performance of agents (as they cannot perfectly and costlessly observe all activities), it is impossible to perfectly align the interests of the agent with the principal. In other words, it is still possible for agents to act against the interests of the principal.

Continuous disclosure is a way of giving investors (the principals) more information that they can use to monitor and assess the performance of the managers. With this additional information, investors are better able to sanction managers who have been acting against the 
interest of investors, and reward those who have served them well. Managers knowing that they are under greater scrutiny will be more likely to act more in interest of investors, because it is now in their own self-interest to do so.

\section{Figure 2: SOE agency relationship}

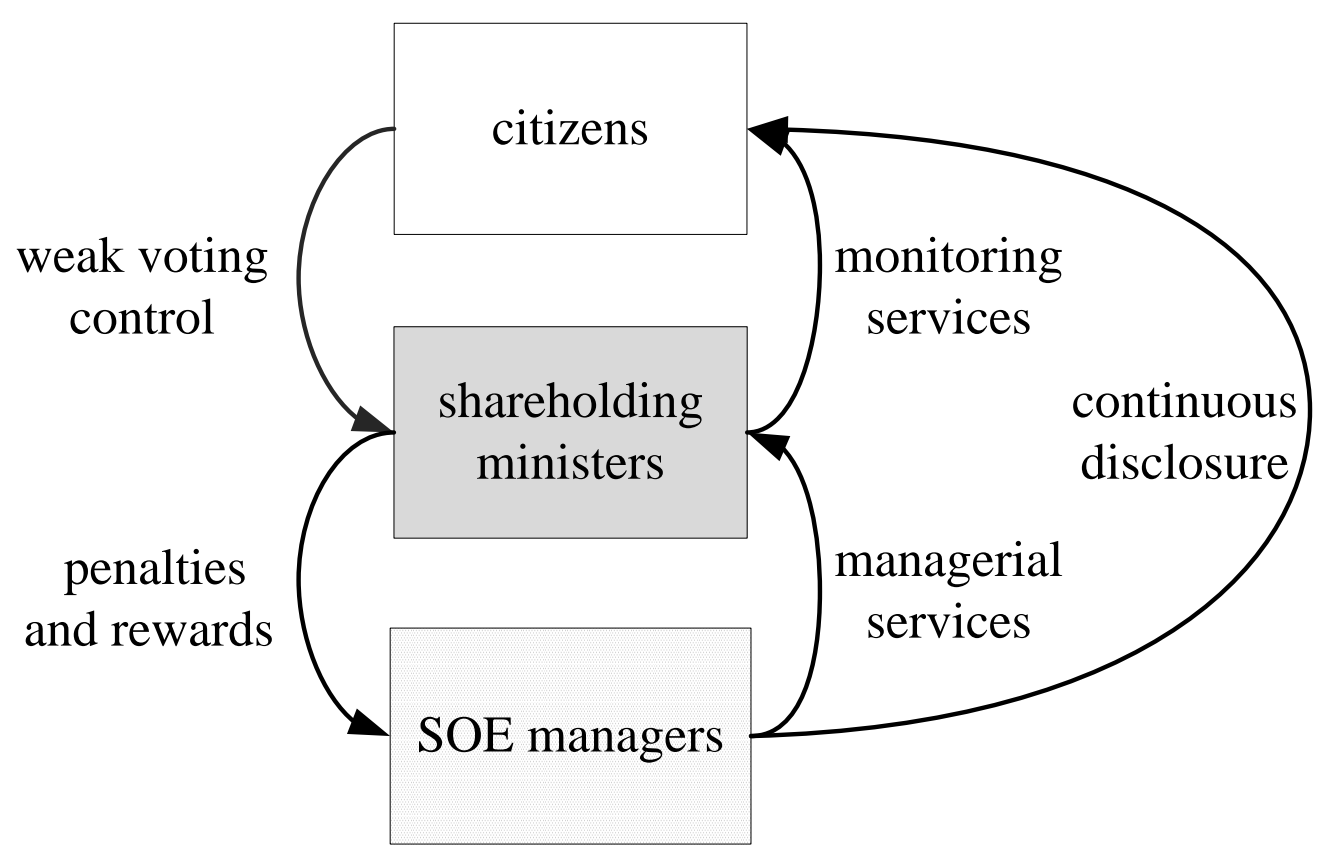

In the case of an SOE, citizens do not interact directly with SOE managers in the capacity of owners ${ }^{10}$. Instead, they delegate this role to the shareholding ministers of the current government. Shareholding ministers have the power to appoint and remove directors, set dividend levels and negotiate an SOE's statement of corporate intent. This leaves the citizens with little to no power to directly influence an SOE or its management. The only way that citizens can influence an SOE is indirectly by voting for a different government. This means there is a dual agency relationship (Figure 2). There is one agency relationship between the citizens (principal) and shareholding ministers (agent), and another agency relationship between the shareholding ministers (principal) and the managers of SOEs (agent).

There are inherent problems in structures with differing allocations of control and ownership rights. Such structures have the potential to create agency costs that are an order of magnitude higher than structures in which control and ownership are aligned (Bebchuk, Kraakman \& Triantis, 2000).

\footnotetext{
${ }^{10}$ Though they may interact with SOEs in other economic 'roles', for example as an employee or as a customer.
} 
The agency relationship between the shareholding ministers and the managers of an SOE is relatively strong. That is, ministers have the potential to directly align the interests of SOE managers with their own. Ownership is concentrated in the two ministers, avoiding the freerider problems of dispersed ownership. The shareholding ministers have the Crown Ownership Monitoring Unit (COMU) to analyse the performance of managers of their behalf and the ministers have the power to appoint and remove SOE directors. As COMU sits within a core ministry (The Treasury), Ministers can direct COMU to report on specific aspects of SOE performance that are of interest to them. Such monitoring activity will inevitably flow through to the incentives SOE managers face - for example, in prioritising the range of activities under their control and allocating resources to them. An example of this is the "no surprises' policy under which SOEs are expected to keep the relevant ministers apprised of any activities or outcomes that might have political consequences. This inevitably leads to constraints on SOE managers' activities that are not faced by PLC managers, and compromises the pursuit of financial performance as the SOE's primary objective.

By contrast the agency relationship between citizens and shareholding ministers is very much weaker. Citizens have scant direct control of shareholding ministers' activities and lack strong incentives to analyse and monitor their performance.

The ability of citizens to control shareholding ministers is weak because of imperfections in the voting mechanism. First, they cannot vote for individual policies; they can only choose from a limited number of 'policy bundles' offered by political parties and candidates. Citizens are unable to vote for all their preferred policies, so they have to decide which are most important and which can be forgone. For example, if a citizen wanted to decrease the level of investment in SOEs, the only choice in the 2008 New Zealand election would have been to vote for the ACT Party (a right-wing political party). However, the ACT Party has other policies it would like to enact, for example removing the Emissions Trading Scheme (ETS, a system designed to lower greenhouse gas emissions). If a voter wanted to decrease their investment in SOEs, but also wants a strong ETS, they would have to decide to sacrifice one policy to enact the other. Therefore, citizens' voting choices may be driven by higher profile or more personally relevant issues than SOE policy.

Second, voting is a noisy information channel. Political parties have only a very approximate understanding of why individuals voted for them. As each party has a plethora of policy positions and each voter has a unique set of preferences over all of these policies, political parties are likely to misinterpret the mandate voters have given them, considerably weakening the control voters have over the shareholding ministers. Third, citizens do not directly vote for 
shareholding ministers. The party leadership selects ministers, and they may give out ministerial positions based on loyalty or political influence rather than past performance or voter preference.

For citizens to undertake any SOE monitoring activity, the benefits of doing so must exceed the costs they expend. Information availability as a consequence of a continuous disclosure obligation alone is not sufficient to prompt individual citizens to undertake more SOE monitoring activity than would have occurred in its absence. Collecting and analysing available information is costly, so there must be a direct benefit that can be accrued by the individual(s) undertaking the activity. Many factors militate against incentivising the average citizen to engage in this costly analysis. First, ownership stakes in SOEs are very widely dispersed with each citizen holding roughly one four-millionth of each SOE. Therefore, each individual has such a small stake in each SOE that the personal benefits from undertaking any meaningful monitoring or analysis (even if they could be internalised) would far outweigh the costs. Second, citizens cannot easily change their level of investment in SOEs because of the imperfections in the voting mechanism noted above. If an analysis of the value of SOEs cannot be used to affect one's level of investment in SOEs, then a citizen has little or no incentive to perform such an analysis.

Therefore, it is highly unlikely that individuals will invest resources in monitoring SOEs in which they cannot control their investment. However, it is possible than an organisation could monitor SOEs on behalf of citizens. Such an organisation could aggregate the interests of a group of citizens, spread the cost of monitoring across this group, and thereby recouping the costs. Financial analysts and the media are two candidates. They have an incentive to monitor if they can sell their analysis directly or use it to sell other products, e.g. newspapers. However, it matters which citizens are prepared to pay for such activities to be undertaken. Given the limited ability for individuals to personally benefit from improved financial performance of SOEs, the citizens for whom the benefits of such analysis exceed the costs are most likely members of sectoral interest groups engaged in political processes, whose strong personal preferences regarding the way the SOE should be managed may not be governed by financial performance imperatives. As the benefits they gain from such activity accrue in the political arena, their monitoring is unlikely to have any material effect upon SOE manager performance against financial objectives. The absence of an effect is reinforced if it is assumed that the SOE structure effectively constrains the extent to which political imperatives can override SOE financial performance objectives. 
It is noted that almost half of NZX-listed companies have no analyst coverage (Capital Market Development Taskforce, 2009). If there is such a limited demand for financial analysis of such a large number of firms where the shares are tradeable, it appears extremely unlikely that demand for analysis of SOE financial performance will be strong. Consequently, analysts will be highly unlikely to offer such services without the ability to trade SOE shares being present.

Another candidate is opposition parties who may use the information obtained from continuous disclosure to hold the shareholding ministers to account. However the outcome of such monitoring is not necessarily consistent with improved SOE performance. For example, it may be in the political interest of parties who favour continued state ownership of SOEs to overlook poor SOE performance. Ironically, making information available that would otherwise not have been obtained by these political agents may actually lead to a reduction in the incentives for SOE managers to pursue financial opportunities in the same manner as would their otherwise-equivalent PLC counterparts. Opposition parties face strong incentives to embarrass rather than reward ministers - making ministers, and SOE managers as their agents, highly risk-averse. This risk aversion may lead to SOE managers rejecting profitable projects due to the presence of political risk rather than utilising the commercial criteria that would normally govern such decisions. It is noted that this effect applies regardless of how well - or otherwise - the SOE structure facilitates management of the extent to which political imperatives can compromise SOE financial performance objectives ${ }^{11}$.

In summary, it appears that three conditions must be satisfied for independent financial monitoring of firms to be justified by any party. First information about the agent's performance is needed. Second the principal needs an incentive to engage in analysis of this information. Third, the principal needs a mechanism through which it can influence the agent. In the case of SOEs, we have found the latter two conditions are absent, thereby reducing the benefits able to accrue from continuous disclosure. As citizens are unable to meaningfully exert the ownership interests of shareholders, most control mechanisms have been deferred to

\footnotetext{
${ }^{11}$ A notable example of this effect (albeit relating to a sharemarket-listed firm where the government is a majority owner and not an SOE) is when it was discovered that Air New Zealand had fulfilled a charter contract with the Australian government under which which two of its planes transported troops to Kuwait in preparation for their engagement in Iraq. Whilst Air New Zealand maintained that the charter was a purely commercial arrangement, and the government was informed of the agreement, the opposition endeavoured to make the matter an issue of political importance. It cannot be discounted that the political consequences arising from this of this contract combined with the 'no surprises' obligations on SOEs, would lead to Air New Zealand (and all SOEs, having observed this matter) eschewing other profitable commercial activities that would have been undertaken without hesitation by a PLC unencumbered by the consequences of political risks. http://www.nzherald.co.nz/nz/news/article.cfm?c_id=1\&objectid=10457904
} 
shareholding ministers. The voting mechanism does not allow citizens strong control of the government when it comes to individual issues. Consequently, citizens have little incentive to undertake time consuming and costly analysis of the information released by continuous disclosure. It therefore appears that the effects of the SOE continuous disclosure regime are more likely to pertain to the operation of political processes, and that these are as likely to compromise the pursuit of improved SOE financial performance as to enhance it.

\section{Credibility, penalties and frequency of disclosure}

Regardless of whether there are economic justifications for the SOE continuous disclosure regime, it is apposite to assess whether the New Zealand regime has in fact increased the amount and quality of information available in the same manner as observed when PLCs became so obligated. That is, are SOEs complying with the obligations, and are the institutional arrangements effective in monitoring and enforcing compliance?

Any continuous disclosure regime will be effective only if both the regime itself, and the information provided, are credible. If investors believe the regime is not being fully complied with, continuous disclosure will be unable to fulfil its purpose. Full compliance requires the effective deterrence of non-compliance. Effective deterrence requires identification, detection, and punishment.

Identification in this context means that it must be possible to evaluate whether or not a particular piece of information is subject to the disclosure regime or not. The 'material effect on the share price' criterion is helpful here, as share price responses to new information (however released) are readily observable. However, an SOE has no observable share price. Therefore, determining whether or not information is material even for a hypothetical share price could be very difficult.

Detection means it must be possible to identify when a specific instance of non-disclosure has occurred. After all, if there is no possibility of non-disclosure being detected, then withholding will likely occur, even when a disclosure obligation exists. Those monitoring and enforcing disclosure agreements 'can never know what they cannot discover'. For a firm with tradeable shares, an act of insider trading actually aids enforcement of a disclosure regime, as a significant share price change otherwise unexplained by information released would indicate that investigation of non-disclosure is warranted. However, as there is no possibility of insider trading in an SOE, detection of non-disclosure in SOEs becomes more difficult. Consequently, the likelihood of non-disclosure increases. 
Punishment refers to the consequences of non-compliance. To ensure compliance when the probability of detection is low, severe sanctions are required. By way of comparison, insurance contracts often include terms to address non-disclosure of information that may have a material effect on the risk associated with cover. Penalties are typically higher the lower the probability of detection. Thus non-disclosure of a criminal record may lead to a whole policy being declared void, rather than relying on a case-by-case examination of the relevance of the withheld information to specific claims. Stiff penalties imposed on those caught not disclosing become a strong deterrent for other potential non-disclosers.

For publicly listed companies in New Zealand, the Securities Commission has primary responsibility for enforcing continuous disclosure. It can issue a disclosure order, which carries a maximum penalty of $\$ 30,000$ if not obeyed, and the courts can issue a pecuniary punishment of up to $\$ 1,000,000$ per defendant. In April 2010, the Commission filed its first case under continuous disclosure regulations against Nuplex Industries Limited and six of its past and present directors. The case is still with the courts, but the Securities Commission has sent a strong signal that noncompliance with continuous disclosure regulations is a serious crime and will be prosecuted. For example, legal firm Kensington Swan recommended directors "err on the side of disclosing information that may be 'material information'."12

With respect to the SOE continuous disclosure regime, as there are no penalties for noncompliance and no obvious means of detecting non-disclosure ex post, given the discussion in the preceding sections, we hypothesise that SOEs will disclose information less frequently than PLCs.

The continuous disclosure regime for SOEs has been in place for over 15 months at the time of writing. This gives us an opportunity to test this hypothesis, and perform an early evaluation of how well the regime is performing. First of all, examples of material information that arguably should have been published on the COMU website but were not, are easy to find. It is important to note that these examples are cases where the SOE released the information via other channels (i.e. it was not 'not disclosed'), but failed to submit the disclosure to COMU for publication. As such, they are very different from cases where material information is not disclosed at all. However, they still show the extent to which SOEs are prepared (or not) to comply with the mechanics of a disclosure regime that directly parallels that with which PLCs are expected to comply.

\footnotetext{
${ }^{12}$ http://www.kensingtonswan.com/Newsletters/Mergers\%20and\%20Acquisitions/Continuous_disclosure_obligations.pdf Accessed 8 December 2010.
} 
By way of illustration, four examples of material information reported in the media that were not submitted to COMU for publication during 2010 are presented. On 27 January Meridian received approval from the Environment Court to build a 52 turbine wind farm ${ }^{13}$. On 24 June Landcorp announced it put in a bid to buy 16 Crafar family farms ${ }^{14}$. Though the size of the bid was not announced, a rival bid by Hong Kong listed Natural Dairy (NZ) Holdings was thought to be around \$210 million, which would indicate that Landcorp's bid would be considered a material transaction under the disclosure rule's definition ${ }^{15}$. On 18 August the Government announced it would provide an uncalled capital facility to NZ Post ${ }^{16}$. On 18 May the Government announced that it would invest a further \$750 million in the New Zealand Rail Corporation (NZRC) over the next two years ${ }^{17}$. Furthermore no disclosure was made regarding NZRC's $\$ 4.6$ billion 10-year turnaround plan $^{18}$. In comparison, for the financial year ending June 2010, NZRC had an Operating Revenue of only $\$ 0.65$ billion. That such a significant, and expensive, strategic change was not accompanied by announcement on COMU's website in our view reflects poorly on the regime.

Secondly, we compared the frequency of disclosures made by SOEs by matching them with publicly-listed counterparts that resemble them as closely as we could determine. ${ }^{19}$ Nine companies listed on the NZX were chosen, a matching company from the same industry and of a similar size for each SOE. ${ }^{20}$ We then counted the number of disclosures made by each over the 15 months for which SOE data was available. Table 1 summarises the findings. Whilst the data sample is too small for econometric testing, the descriptive statistics show that on average the PLCs made nearly four times as many disclosures as the SOEs.

\footnotetext{
${ }^{13}$ http://new.nbr.co.nz/article/meridian-given-approval-wind-farm-117624 Accessed 1 December 2010.

${ }^{14}$ http://www.nzx.com/news/3847155/Landcorp-to-make-bid-for-Crafar-farms Accessed 1 December 2010.

${ }^{15}$ The SOE disclosure rules state that a transaction is considered material if the consideration payable or receivable is greater than $5 \%$ of the SOE's current commercial value. Landcorp's current commercial value is estimated at \$1.27 billion, meaning any transaction greater than $\$ 63$ million is material.

${ }^{16}$ http://beehive.govt.nz/release/government-support-nz-post-plans Accessed 8 December 2010.

${ }^{17}$ http://www.nbr.co.nz/article/250-million-kiwirail-pre-budget-announcement-123174 Accessed 8 December 2010.

${ }^{18}$ http://www.kiwirail.co.nz/uploads/KiwiRail\%20Turnaround\%20Plan\%20(Brochure).pdf Accessed 10 December 2010.

${ }^{19}$ When counting the number of disclosures made by SOEs, periodic disclosures such as the announcement of annual reports have been excluded, since we are only considering continuous disclosures. For PLCs, only disclosures listed as price sensitive on NZX's company research database are included. The time period in which disclosures are counted is 1 January 2010 to 21 April 2011 for both SOEs and PLCs.

${ }^{20}$ These companies are: Freightways, Horizon Energy, Contact Energy, Trustpower, PGG Wrightson, Vector, Air New Zealand, NZ Oil and Gas and TeamTalk.
} 
Table 1: Frequency of disclosure

\begin{tabular}{|l|r|r|}
\hline Number of disclosures & SOEs & PLCs \\
\hline Average & 4.33 & 15.11 \\
\hline Highest & 11 & 39 \\
\hline Lowest & 1 & 3 \\
\hline
\end{tabular}

A much more detailed and accurate analysis could be performed if the regime were in for a longer time period, and if there were a greater number of SOEs for comparison. Furthermore, we have not controlled for the quantity or quality of information contained in each disclosure. However, Table 1 reveals that SOEs are disclosing substantially less frequently than their publicly listed counterparts. Whilst it is possible that the group of SOEs happened to have four times less material information to disclose, it is an unconvincing explanation, given that the PLCs were competing in the same industry and were of similar size as the SOEs. Thus, we suggest that the data appears to support our hypothesis that, as a consequence of both weaker incentives and inadequate compliance mechanisms arising from the differences in ownership and governance arrangements, SOEs subjected to a continuous disclosure regime modelled on that applied to PLCs are disclosing less frequently, and likely less information, than their PLC counterparts.

\section{Conclusion}

The New Zealand SOE continuous disclosure obligation represents a continuation of the transferral of instruments shown to improve managerial accountability and hence financial performance from the private sector into the public sector. However, it is difficult to conclude, on the basis of our theoretical and empirical analysis, that the continuous disclosure regime applied to New Zealand SOEs will have a material effect upon the financial performance of SOEs, at least by the mechanisms proposed in the policy supporting its implementation. Whist transparency might appear a laudable objective to pursue in its own right, the mere availability of more information is insufficient to encourage the extent of monitoring and enforcement necessary to hold managers accountable for their performance. In the absence of ownership interests directly benefiting from the monitoring and enforcement effort exerted, and governance instruments via which information discovered in that endeavour can be utilised by its discoverers to alter the incentives facing SOE managers in a manner that compensates the discoverers for their efforts, it is unlikely that an obligation to disclose will have any material financial performance effect. 
SOEs differ from their PLC counterparts in precisely the dimensions of owner identity and governance mechanisms that have been demonstrated to sit at the core of efficient and effective operation of private sector continuous disclosure regimes. For PLCs, continuous disclosure is just one part of an interlocking system of ownership and governance mechanisms that create sharp performance incentives for managers. Each mechanism performs best when in combination with others that are consistent with each other. If continuous disclosure is to have the same performance improvement effects on SOEs, then both their ownership and governance arrangements must be altered to more closely resemble those of PLCs.. Whilst it is beyond the scope of this paper to create or comment upon policies in this area, it is noted that the partial listing of SOEs as has been proposed in recent policy discussions would make it much more likely that the financial performance improvement objectives of a continuous disclosure regime would be achieved than from the imposition of the disclosure regime alone. 


\section{References}

Akerlof, G. (1970). The Market for Lemons: Qualitative Uncertainty and the Market Mechanism. Quarterly Journal of Economics. 84: 488-500.

Ausubel, L. (1990). Insider Trading in a Rational Expectations Economy. The American Economic Review. 80 (5), 1022-1041.

Bebchuk, Lucian A., Kraakman, Reinier, \& Triantis, George. (2000). Stock Pyramids, CrossOwnership, and Dual Class Equity: The Creation and Agency Costs of Separating Control from Cash Flow Rights. In R. Morck (Eds.), Concentrated Corporate Ownership, pp. 295-315; Harvard Law and Economics Discussion Paper No. 249. Available at SSRN: http://ssrn.com/abstract=147590.

Bhattacharya, U., \& Daouk, H. (2002). The World Price of Insider Trading. The Journal of Finance. 57 (1), 75-108.

Boles de Boer, D., \& Evans, L. (2000). Economic Performance of Five State-Owned Enterprises 1989-1998. Retrieved February 25, 2011, from: http://www.iscr.org.nz/f239,4816/4816_soe_report_160600.pdf.

Capital Market Development Taskforce. (2009). Capital Markets Matter. Retrieved May 5, 2011, from: http://www.med.govt.nz/upload/71047/MDV6220_CMD_TombStone_04c.pdf.

Coase, R. H. (1960). The Problem of Social Cost. Journal of Law and Economics. 3, 1-44.

Coffee, J. (1984). Market Failure and the Economic Case for a Mandatory Disclosure System. Virginia Law Review , 70 (4), 717-753.

COMU (2010). 2010 Annual Portfolio Report. Crown Ownership Monitoring Unit, Wellington New Zealand. 7 December 2010. Retrieved February 25, 2011 from: http://purl.oclc.org/nzt/apr-1340.

Dennis, R. J. (1987). Mandatory Disclosure Theory and Management Projections: A Law and Economics Perspective. Maryland Law Review, 46 (4), 1197-1221.

Dunstan, K., Gallery G. \& Truong T. P. (2008). The Impact of New Zealand's StatutoryBacked Continuous Disclosure Regime on Corporate Disclosure Behaviour. Centre for Accounting, Governance and Taxation Research Working Paper Series. No. 63.

Easterbrook, F. H., \& Fischel, D. R. (1984). Mandatory Disclosure and the Protection of Investors. Virginia Law Review , 70 (4), 669-715.

Eisenhardt, Kathleen M. (1989). Agency Theory: An Assessment and Review. The Academy of Management Review. 14 1. pp.57-74.

Etebari, A., Tourani-Rad, A., \& Gilbert, A. (2004). Disclosure regulation and the profitability of insider trading: Evidence from New Zealand. Pacific-Basin Fiance Journal , 12 (5), 479-502. 
Horn, M. (1995). The Political Economy of Public Administration: Institutional Choice in the Public Sector. Cambridge, UK: Cambridge University Press.

Jensen, M. (1993). The Modern Industrial Revolution, Exit, and the Failure of Internal Control Systems. The Journal of Finance. 48(3): 831-80.

Jensen, M. C., \& Meckling, W. H. (1976). Theory of the Firm: Managerial Behavior, Agency Costs and Ownership Structure. Journal of Financial Economics , 3 (4), 305-360.

Manove, M. (1989). The Harm From Insider Trading and Informed Speculation. The Quarterly Journal of Economics. 104 (4), 823-845.

Milgrom, P., \& Roberts, J. (1992). Economics, Organisation and Management. Upper Saddle River, New Jersey: Prentice Hall.

Ojah, K., Muhanji, S., \& Myburg, A. (2008). Market Reaction and Equity Market Efficiency: A Survey of the Insider Trading Law in South Africa. African Finance Journal. 10 (2), $1-28$.

Pastena, V., \& Ronen, J. (1979). Some Hypotheses on the Pattern of Management's Informal Disclosures. Journal of Accounting Research. 17 (2), 550-564.

Prendergast, C. (2003). The Limits of Bureaucratic Efficiency. Journal of Political Economy. 111(5): 929-58. 